\title{
AN OUTLINE OF A STRATEGIC MAP OF MUNICIPALITIES WITH THE USE OF THE BALANCED SCORECARD METHOD
}

\author{
[Náčrt strategické mapy obcí s využitím metody Balanced Scorecard] \\ Petr $\check{R ̌ e h o r ́}^{1}$
}

${ }^{1}$ Jihočeská univerzita v Českých Budějovicích, Ekonomická fakulta, Studentská 15, 37005 České Budějovice
Email:rehor@ef.jcu.cz

\begin{abstract}
The article covers the compilation of a strategic map of four municipalities in a montane and submontane area in the region of The Novohradske Mountains in South Bohemia. The map was compiled on the basis of the Balanced scorecard (BSC) method. It is a tool by which the fulfilment of a municipality strategy can be monitored and it is used for an effective management of strategies. In other words it means a method of balanced indicators or balanced prosperity. Goals and benchmarks of BSC come from vision and strategy of these municipalities and they monitor their performance from four perspectives: customer, financial, internal processes, learning and growth. These four perspectives are clearly depicted in the strategic map and each one has more detailed definitions of benchmarks of their fulfilment.
\end{abstract}

Keywords: balanced scorecard, management, montane and submontane area, municipality, strategic map, strategy, vision.

JEL classification: $\mathrm{H} 11, \mathrm{R} 58$

Doručeno redakci: 7.10.2011; Recenzováno: 28.5.2013; 24.4.2013; Schváleno k publikování: 16.6.2014

\section{Introduction}

Orientation in unstable conditions, finding a proper direction and selection of a suitable way to the future goals includes the key role of the strategic management (Demjanová, Carnický, 2011). Public administration and self-governing bodies (regions, municipalities) go through a number of reforms, whose main aim is to increase efficiency in particular. Vision of the state of public administration in 2015 is as follows:

$>$ Public administration in the Czech Republic is primarily understood as a service for citizens, it fulfils principles of good governance, it functions effectively and efficiently.

$>$ Public services are client oriented, they fulfil expectations of citizens, they respond in an adaptive way to the needs of citizens and they function efficiently.

$>$ Public administration and public services contribute to higher competitiveness of the Czech Republic. They increase the quality of life of people in the Czech Republic (Efektivní veřejná správa, 2007).

The way how to attain such state could come through assertion of methods of quality management (BSC is one of them). Their implementation was first started in private sector. These days they are making their way into public sector as well. They provide organizations with important information about their efficiency, strengths and weaknesses, customer satisfaction with their functionality or about possibility of improvement and development.

\section{Balanced Scorecard (BSC)}

The BSC method originated in the USA and it is not used only there, but also in Europe, with great success in companies and in organizations of public sector as well. The name of the method is either not translated into Czech language or we can come across the name „The Method of balanced indicators (of success)“ (Hušek a kol., 2006). The original concept was created at the beginning of the 90 s by professors Kaplan and Norton. 
The BSC method is a tool by which the fulfilment of an organization strategy can be monitored and it is used for management of strategies. On the whole it enables the organizations to clarify their visions and to enterprise strategies and to turn them into real operations (Cobbold, Lawrie, 2002). The method supplements previously preferred financial benchmarks of previous performance and new benchmarks of future performance of subjects (Karathanos, 2005).

BSC has a great communication significance either within an organization (procurement of strategy all the way to level of employees), or outside of it. In public sector there is a need and a significance of communication even greater - the aims of politics have to be explained to citizens and at the same time it is necessary to show the ways how these goals can be achieved. In public sector, the BSC method should focus on two main goals. They are „political governing“ (mainly internal) and „political communication“ (mainly external) (Hrabalová a kol., 2006) - see picture 1.

Figure 1: Double function of BSC in public sector

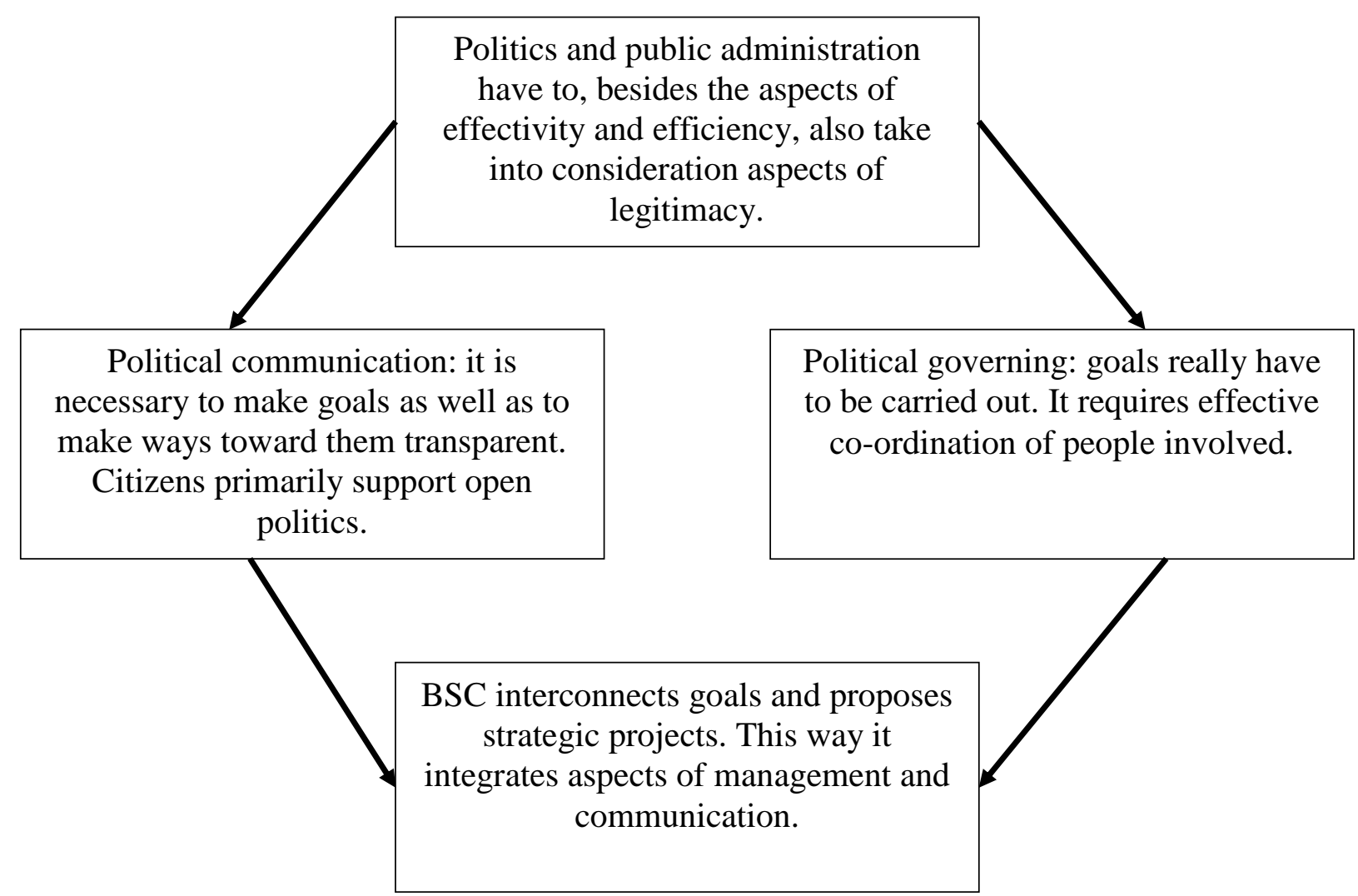

Source: Horváth \& Partners, 2002. Balanced Scorecard v praxi. Praha: Profess Consulting. ISBN 80-7259-018-9

The aim of this model is to improve the process of strategic planning of an organization. With its help, there should be a significantly greater probability to implement the intended strategies (Horváth and Partners, 2002). The acceptance of BSC was considerably slower in a public and non-profit sector. This phenomenon is also noticed by Niven (2003) - he explains it as an aversion of non-profit organizations to experiment with tools used by companies that are profit oriented. Such an approach could obscure the original role of an organization which is not focused on profit. Primary specific of application of the BSC method in public sector is the fact that public institutions have to, in the first place, observe legitimacy and transparency of their activities and put a much greater emphasis on the communication function of BSC (Wisniewski, Olaffson, 2004). 


\section{Aim and methodology}

The aim of the article is to compile, on the basis of the BSC method, the overall strategic map of four municipalities that are located in a montane and submontane area in the region of The Novohradske Mountains in South Bohemia, and further to provide each BSC perspective with at least two benchmarks intended for future inspection of attainment of partial strategies. Municipalities were chosen in the given region because of requirements for solution of research intent in less-favoured areas (LFA) regions. Only four selected municipalities have elaborated a long-term strategic plan of their development, on the basis of which the strategic map can be compiled. Given strategic plans were obtained by the author on websites of each municipality. Some information, mainly on financing municipalities, was obtained by the author on the basis of interviews with mayors of these municipalities.

\section{$3 \quad$ BSC and strategic map of municipalities}

Every municipality should take care of the development of its own area, economic stability, economy of the municipality, and also provide for needs of its citizens and particularly improve the quality of their life (MMR, 2006, Řehoř, 2010).

\subsection{Vision}

Strategic management and strategic planning are of paramount importance for the right function of self-governing bodies. Vision is the integral part of these plans. It represents a long-term conception of function of the given municipality. LFA municipalities have the following brief and longer visions:

$>$ Borovany: to provide citizens, tourists and entrepreneurs with attractive environment, living and economic conditions, quality services and sufficient enough facilities for citizens (Rosa, 2004).

$>$ Český Krumlov: a town with historic heritage of worldwide significance, we are all part of a great cultural, natural and human treasure and the future rests on our decision (Různí, 2002).

$>$ Kaplice: a quiet town profiting from its great strategic location (Různí, 2007).

$>$ Nové Hrady: unique natural, cultural and historic surroundings of town together with good availability of work, housing and facilities for leisure time are prerequisites for a high level of quality living of local inhabitants (Rosa, 2008).

\subsection{Strategic priorities and benchmarks}

On the basis of detailed analysis of strategic plans and knowledge of the BSC method, the overall strategic map (picture 2) was compiled, including key priorities of municipalities in LFA region related to individual perspectives of this method.

Subsequently, for each strategic priority and perspective of BSC, benchmarks were compiled. They can better assess a degree of their fulfilment. At chosen indicators is given a specific value on the example of Nové Hrady in the year 2011.

1. Development of transportation and housing infrastructure: quality of transport services (on the base of citizen evaluation - mark 2), distance from larger towns (35 km from České Budějovice), diversity of transportation (by car, by train or by bus), creating new housing units (7 new houses), new network of streets, pavements (2 pavements), selection of developing sites for construction with prepared infrastructure (1 developing site).

2. Employment and enterprise: arrival of new companies into town (zero), number of current companies in town and its surroundings (551 companies), co-operation with research institutes (1 - South Bohemia University), degree of unemployment (6\%), intensity of entrepreneurial activity (22\%). 


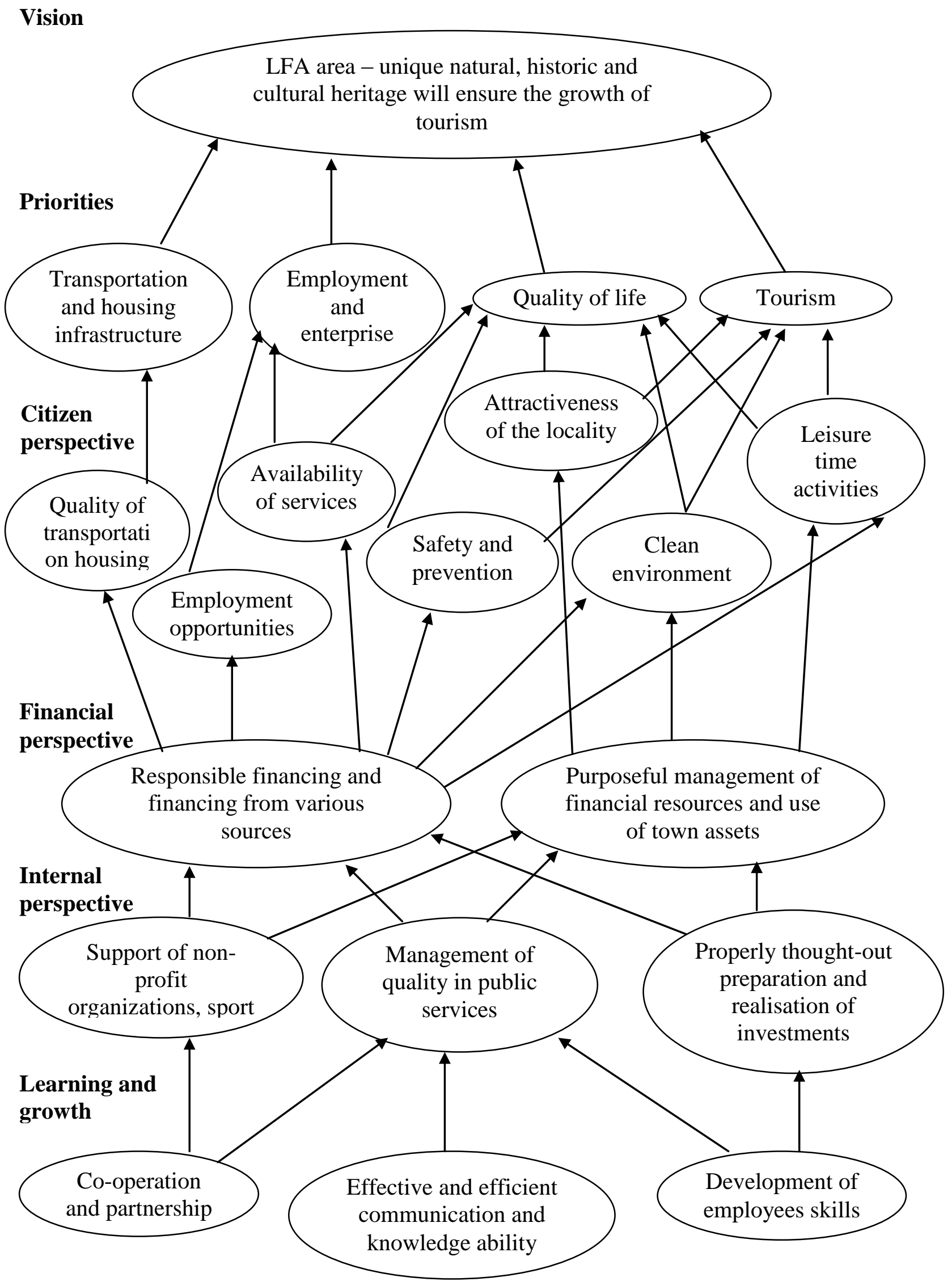

Source: author 
3. Quality of life: lower crime rate in town and its surroundings, availability of services (basis services are available in Nové Hrady), citizen satisfaction index (mark 2).

4. Tourism: number of tourists, longer stay of tourists (only 2 days), public awareness of the locality, number of housing and eating facilities (54), money gained from tourism, improvement of destination management (no destination management in Nové Hrady), grants and subsidies ( 3 realized projects).

\subsection{BSC perspectives and benchmarks}

\section{Citizen perspective}

1. Quality of transportation, housing: number of created new housing units, number of built new family houses.

2. Employment opportunities: quantity of jobs available, number of employed, number of unemployed, monthly average salary in the locality, distribution of household expenses.

3. Availability of services: availability and number of services, spectrum of facilities.

4. Safety and prevention: health of inhabitants, sense of safety, degree of accident frequency, quantity of crime and offences, number of prevention projects and activities.

5. Attractiveness of the locality: number of organized cultural and sporting events, number of attractive sights, number of parcels for development, reconstruction costs, number of visitors of historical sights.

6. Clean environment: number of parks and ponds, wooded areas, upkeep of town greenery.

7. Leisure time activities: number of clubs and associations, number of cycling trails, renovation of sport facilities and construction of new ones, options for sport activities.

\section{Financial perspective}

8. Responsible financing and financing from various sources: volume of acquired grants vs. the budget, volume of finances from other sources, number of created projects.

9. Purposeful management of financial resources and use of town assets: proportion of operation costs to resources, use of town assets, evaluation of effectiveness of investments, indebtedness of town, spare funds in a budget, accounting audit.

\section{Internal processes perspective}

10. Properly thought-out preparation and realisation of investments: number of investments, return on investments.

11. Management of quality in public services: number of complaints, assessment of performance, quality and performance of the authority according to the CAF method, customer satisfaction.

12. Support of non-profit organizations, sport activities: degree of financial support, efficiency and serviceability of support.

\section{Learning and growth perspective}

13. Co-operation and partnership: number of joint projects, willingness of surrounding towns to co-operate, benefits offered by surrounding towns, publicity and promotion.

14. Development of employees skills: quantity of training, qualification of personnel at the local authority office, employee satisfaction.

15. Effective and efficient communication and knowledge ability: quality of communication in a team, employee satisfaction, accessibility of information, upgrade and modernization of technologies. 


\section{Conclusion}

For each municipality it is important to map the given area, the environment and the complete impression of the whole region. That is what the strategic plan is used for. Besides the analysis of a current state it also provides a view on sustainable development in future time ( ̌̌ehor, 2010). The biggest opportunity and strategic priority number 1 for LFA region of The Novohradske Mountains is the growth of tourism. Plenty of historical sights and beautiful unspoiled nature are a great and unfulfilled potential. Increased knowledge and a presentation of the region in the Czech Republic and also in Austria would help increase the number of visitors.

For future growth of the given region it is also necessary to improve infrastructure, which is an absolute weakness now. The most important priority is to repair local communication which is much damaged in less accessible areas. It would be also good to build more information boards, educational trails and cycling trails that would increase activities in leisure time.

Socio-economic development of municipalities and of a region is supported mainly by effective use of the EU structural funds. At present time it is possible to submit applications for grants from various European funds or from Ministry for Regional Development as well as Ministry of culture. Participating municipalities would also gain from a co-operation with Austrian municipalities located near the border and take advantage of their experience.

Accomplishment of all strategies from the strategic map of Novohradsko will be visible in the course of time. Mayors of selected municipalities have already had three years to fulfil the goals that they had intended to achieve, as well as those goals that they or their predecessors had obliged to accomplish in elaborated strategic plans. The results of the paper were already given to representatives of the cities. They can contribute with their decisions to better the citizen satisfaction and the improvement of their lives.

\section{Acknowledgement}

This article has been presented with the financial support of the project: GAJU 039/2013/S.

\section{References}

[1] COBBOLD, I. and G. LAWRIE, 2002. The Development of the Balanced Scorecard as a Strategic Management Tool. Boston: PMA Conference [online]. 2002 [vid. 10. September 2011]. Available from:<http://www.2gc.co.uk/pdf/2GC-PMA02-1f.pdf >.

[2] DEMJANOVÁ, L. a Š. ČARNICKÝ, 2011. Systém strategického pozorovania vo vzt'ahu $\mathrm{k}$ faktorom externého prostredia a podnikovej stratégii. Acta academia karviniensia, 11(4), 56-68. ISSN 1212-415X.

[3] EFEKTIVNÍ VEŘEJNÁ SPRÁVA A PŘÁTELSKÉ VEŘEJNÉ SLUŽBY, 2007. Strategie realizace Smart Administration v obdobi 2007-2015 [online]. 2007 [vid. 12. September 2011]. Dostupné z: 〈http://www.smartadministration.cz/file/9>.

[4] HORVÁTH \& PARTNERS, 2002. Balanced Scorecard v praxi. Praha: Profess Consulting. ISBN 80-7259-018-9.

[5] HRABALOVÁ, S., S. NUNVÁŘOVÁ a I. OPLUŠTILOVÁ, 2006. Řizení místních samospráv. Brno: Masarykova univerzita. ISBN 80-210-4158-7. 
[6] HUŠEK, Z., M. ŠUSTA a M. PU゚ČEK, 2006. Aplikace metody Balanced Scorecard (BSC) ve veřejném sektoru. Praha: Národní informační středisko pro podporu jakosti. ISBN 80-02-01861-3.

[7] KARATHANOS, D. and P. KARATHANOS, 2005. Applying the Balanced Scorecard to Education. Journal of Education for Business, 80(4), 222-230. ISSN 1368-3047.

[8] MMR ČR, 2006. Strategie regionálního rozvoje České republiky na roky 2007-2013 [online]. 2006 [vid. 1. September 2011]. Dostupné z: <http://www.mmr.cz/Regionalnipolitika/Koncepce-Strategie/>.

[9] NIVEN, P. R., 2003. Balanced scorecard step-by-step for Government and Nonprofit Agencies. New Jersey: John Wiley \& Sons, Inc. ISBN 0-471-42328-9.

[10] ROSA, 2004. Strategický plán rozvoje Borovan [online]. 2004. [vid. 12. September 2011]. Dostupné z: <http://www.borovany-cb.cz/strategicky-plan-rozvoje-borovan/d16742>.

[11] ROSA, 2008. Nové Hrady, strategický plán [online]. 2008. [vid. 12. September 2011] Dostupné $\quad$ z: $\quad<$ http://www.novehrady.cz/strategicky-plan-rozvoje-mesta/ds$1132 / \mathrm{p} 1=2629>$.

[12] RŮZNÍ, 2002. Strategický plán rozvoje města Český Krumlov [online]. 2002. [vid. 12. September 2011]. Dostupné z: <http://www.ckrumlov.cz/cz1250/mesto/soucas/ i_udrzit.htm>.

[13] RŮZNÍ, 2007. Realizační program města Kaplice [online]. 2007. [vid. 12. September 2011 Dostupné z: <http://www.mestokaplice.cz/goto.php?id=\&site=zpravy_detail\&from $=\&$ element $=607 \&$ limit $=130 \&$ category $=$ M\%DA\%20-\%20Informace $>$.

[14] ŘEHOŘ, P., 2010. Metody hodnocení potenciálu regionů se zaměrením na trh práce. Brno: Akademické nakladatelství CERM. ISBN 978-80-7204-735-2.

[15] ŘEHǑ̌, P., 2010. Strategický plán rozvoje obcí. Auspicia, 7(1), 34-37. ISSN 12144967.

[16] WISNIEWSKI, M. and S. OLAFFSON, 2004. Developing balanced scorecard in local authorities: a comparison of experience. International Journal of Productivity and Performance Management, 53(7), 602-610. ISSN 1741-0401. 